\title{
【シンポジウム 12】
}

\section{健康科学を牽引する基礎細胞生物学の最前線}

\author{
古市泰郎 ${ }^{1}$, 星 野太 佑 ${ }^{2}$ \\ (1 首都大学東京人間健康科学研究科, 2 電気通信大学情報理工学域基盤理工学専攻)
}

心身が健康であるためには，全身の臓器が正しく機能 する必要があり，そのためには，臓器を構成する細胞が 正しく振る舞う必要がある。細胞の巧妙な仕組みの理解 に挑む細胞生物学は, 健康を維持して病気から遠ざかる 手がかりを見出し, 体力医学の発展にも大きく貢献する.

生命医科学はその歴史の中で, 既成概念が大きく転換 されるパラダイム・シフトを何度か経験してきたが, そ れらの端緒には, 極めて重要な生理作用を持つ分子の同 定や, 不可能とされていた測定の実現，あるいは新しい 数理解析手法の開発といった, インパクトのある発見が 必ずあった。本シンポジウムでは, 健康科学の分野に対 して大きな影響を与え, 新しい潮流を生み出すに違いな い発見をした 4 名のシンポジストから, 最新の研究をご 紹介いただく。

䢐鍋氏（首都大学東京）は加齢や疾患による筋力低下 の原因解明とその治療薬の開発を見据え, 培養骨格筋細
胞の「筋力」を定量的に測定することに成功した。御策 氏（金沢大学）はインスリン抵抗性を惹起する肝臓由来 の液性因子が，運動抵抗性の原因分子であることを発見 し, 運動の健康効果を増強させる薬の開発に道を拓いた。 トランスオミクスと呼ばれる複数のオミクス階層を統合 的に解析する手法を開発した柚木氏（理化学研究所）は, その手法を応用することで, 脂肪細胞のインスリンによ る新たな糖代謝調節機構を明らかにした。山本氏（京都 大学）は全ての細胞の活動に必要なATPを, 生体内で 可視化するシステムを開発し，これまで知り得なかった 1 細胞レベルでの ATP動態をリアルタイムで観察する ことを可能にした。

本シンポジウムにおける登壇者の発表には, 次世代の 健康科学・体力医学の研究に繋がるようなヒントがある と期待し，活発な議論をしていただきたい.

\section{骨格筋細胞の張力を測定する新技術}

\author{
眞 鍋 康子 \\ (首都大学東京人間健康科学研究科)
}

超高齢化社会を迎えている日本では, 加齢に伴って筋 の量や質が低下する筋萎縮（サルコペニア）により，介 護が必要になる高齢者が増加の一途をたどっている，骨 格筋量の減少は全身の疾病を引き起こす要因になる。ま た, 筋量の維持は個人の QOL 維持とも深く関係するこ とから, 健康寿命延伸の観点からも, 筋萎縮の病態解明 と治療法の確立が強く望まれている。

筋の収縮力は萎縮度を全体的に捉える良い指標となる ことから, ヒトのサルコペニアの重要な判定基準の 1 つ となっている。そのため, 筋萎縮の研究方法では, モデ ル動物やヒトを対象に筋力を測定するのが主流である。 基礎研究では倫理的, 時間的, 経済的な障壁の比較的小 さい骨格筋細胞が汎用されているが, 現在のところ骨格
筋細胞を用いて筋の収縮力を判断できる手法はなく，骨 格筋細胞のタンパク質合成能力や分解を指標とした間接 的な測定で筋萎縮やその改善度を判断しており, 細胞を 用いた収縮力測定系の開発が必要とされている。

本シンポジウムでは，今回新たに我々が開発した骨格 筋細胞の収縮力を測定する系について発表する。本手法 は, 以前に開発された平滑筋細胞が常時発揮している力 を測定する技術（Saito et. al., Biotechnol Lett, 2014）を 改良した系で，骨格筋が瞬時に収縮する時の収縮力の測 定に応用した。

筋細胞を用いた収縮力の測定手法はこれまでになかっ たため, 本手法は薬品・食品メーカーなどが筋萎縮を予防・ 改善する製品の開発時に強力なツールになると考える. 